\title{
PERKAWINAN DI BAWAHUMUR DITINJAU DARI HUKUM PERKAWINAN (STUDI DI DESA MAIT HILIR) KECAMATAN SEPAUK KABUPATEN SINTANG
}

\author{
Michell Eko Hardian \\ Fakultas Hukum Universitas Kapuas Sintang \\ Jalan Oevang Oeray 92 Sintang \\ Email : ekotuah@gmail.com
}

\begin{abstract}
Abstrac
Underage marriage is a frequent social phenomenon in our society, as happened in Mait Hilir Village, Sepauk Sub-District, Sintang District, which has violated the Marriage Law No. 1 Year 1974 Article 7, states that marriage is only permitted if the man has reached the age of 19 years and the woman has reached the age of 16 years, but the dispensation allows the marriage couple to do underage marriage, this thesis trying to uncover What are the conditions of marriage in the underage and what is the cause of the underage marriage.
\end{abstract}

Keywords: Marriage, underage

\begin{abstract}
Abstrak
Perkawinan di bawah umur menjadi sebuah fenomena sosial yang sering terjadi di masyarakat kita, seperti yang terjadi di Desa Mait Hilir, Kecamatan Sepauk Kabupaten Sintang yang telah menyalahi UndangUndang Perkawinan No. 1 Tahun 1974 pasal 7, menyebutkan bahwa perkawinan hanya
\end{abstract}

diizinkan jika pihak pria sudah mencapai umur 19 tahun dan pihak wanita sudah mencapai umur 16 tahun, namun adanya dispensasi memungkinkan pasangan pengantin untuk melakukan Perkawinan di bawah umur, Skripsi ini mencoba mengungkap Apa saja syarat perkawinan di bawah umur tersebut dan Apa yang menjadi penyebab terjadinya Perkawinan di bawah umur tersebut.

Kata Kunci :Perkawinan, dibawah umur

\section{Latar Belakang}

Setiap orang atau pasangan (pria dengan wanita) jika sudah melakukan perkawinan maka terhadapnya ada ikatan kewajiban dan hak diantara mereka berdua dan anak-anak yang lahir dari perkawinan tersebut. Perkawinan menurut Undang-Undang Nomor 1 tahun 1974 tentang Perkawinan (selanjutnya disebut UU Perkawinan)1, bukan hanya merupakan suatu perbuatan perdata saja, akan tetapi juga merupakan suatu perbuatan keagamaan, karena sah atau tidaknya suatu perkawinan tolak ukurnya sepenuhnya ada 
pada hukum masing-masing agama dan kepercayaan yang dianutnya.

Ikatan perkawinan merupakan unsur pokok dalam pembentukan keluarga yang harmonis dan penuh rasa cinta kasih, maka dalam pelaksanaan perkawinan tersebut, diperlukan norma hukum yang mengaturnya. Penerapan norma hukum dalam pelaksanaan perkawinan terutama diperlukan dalam rangka mengatur hak, kewajiban, dan tanggung jawab masing-masing anggotakeluarga, guna membentuk rumah tangga yang bahagia dan sejahtera.

Persoalan yang mengemuka yang terjadi di Desa Mait, Kecamatan Sepauk Kabupaten Sintang adalah Perkawinan di bawah umur. Perkawinan di bawah umur adalah pernikahan yang dilakukan calon mempelai yang belum mencapai batas usia yang ditentukan undang-undang No. 1 tahun 1974, yaitu laki-laki berusia 19 tahun dan perempuan berusia 16 tahun. Prinsip yang dianut dalam Undang-Undang No. 1 tahun 1974 ini adalah bahwa calon suami istri itu harus telah masak jiwa raganya untuk dapat melangsungkan pernikahan, supaya dapat mewujudkan tujuan perkawinan secara baik tanpa berakhir pada perceraian dan mendapat keturunan yang baik dan sehat. Untuk itu harus dicegah adanya perkawinan antara calon suami istri yang masih di bawah umur. ${ }^{16}$ Selain menimbulkan masalah sosial, perkawinan di bawah umur bisa menimbulkan masalah hukum.

Pasal 7 Undang-Undang No. 1 Tahun 1974 tentang Perkawinan menyebutkan bahwa perkawinan hanya diizinkan jika pihak pria sudah mencapai umur 19 tahun dan pihak wanita sudah mencapai umur 16 tahun.Namun penyimpangan terhadap batas usia tersebut dapat terjadi ketika ada dispensasi yang diberikan oleh pengadilan ataupun pejabat lain yang ditunjuk oleh kedua orang tua dari pihak pria maupun pihak wanita.

Untuk melaksanakan hal tersebut, maka kedua orang tua laki-laki maupun kedua orang tua perempuan dapat meminta dispensasi atas ketentuan umur kepada Pengadilan Agama bagi yang beragama Islam dan Pengadilan Negeri bagi yang non-Islam (Pasal 7 ayat [2] UUP jo. Pasal 1 huruf b PPNo. 9 Tahun 1975 tentang Pelaksanaan UU No. 1 Tahun 1974 tentang Perkawinan). Pengajuan dispensasi tersebut diajukan ke pengadilan sesuai wilayah tempat tinggal pemohon.

\section{Pembahasan}

\section{A. Gambaran Umum Lokasi Penelitian}

Kecamatan Sepauk memiliki luas wilayah sebesar $307.65 \mathrm{Km} 2$, terdiri dari

16 http://www.suduthukum.com/2017/03/ pengertian-pernikahan-di-bawah-umur.html 
40 desa dan memiliki 124 dusun, 333 Rukun

Tetangga. Dengan jumlah penduduk sampai hingga tahun 2014 sebesar 49.678 jiwa dengan tingkat kepadatan penduduk 27 jiwa per $\mathrm{km}^{2}$ dan kepadatan per dusun mencapai 404 jiwa. ${ }^{17}$

Salah satu Desa yang terdapat di Kecamatan Sepauk adalah Desa Mait Hilir yang terletak pada $111.27{ }^{\circ}$ BT $0.06^{\circ} \mathrm{LS}$ dengan luas $70,27 \mathrm{~km}^{2}$ atau $3,85 \%$ dari keseluruhan luas kecamatan Sepauk dan jumlah penduduk 1.507 jiwa dengan jumlah 394 Kepala Keluarga yang dibagi dalam 4 Dusun dengan 9 RT, dengan kepadatan 21orang per $\mathrm{km}^{2}$. Sebagian besar 84 persen bermata pencaharian sebagai petani. ${ }^{18} \mathrm{Jarak}$ Desa Mait Hilir dengan Pusat Kecamatan di Sepauk sejauh 25 Kilometer dan 40 kilometer dari Kota Sintang. Dengan Batas Desa sebagai berikut :

Sebelah Barat $\quad$ : Berbatasan dengan Desa Tanjung Balai

Sebelah Timur $\quad$ : Berbatasan dengan Desa Mengkurat Baru

Sebelah Selatan : Berbataan dengan Desa Peribang Baru

Sebelah Utara : Berbatasan dengan Desa Paoh Benua

17 Badan Pusat Statistik Kabupaten Sintang Katalog 1102001.6107110 "Kecamatan Sepauk Dalam Angka2015

18 Sumber Data Desa Mait Hilir, Wawancara dengan Kepala Desa Mait Hilir
Jumlah sekolah di desa Mait Hilir ada

1 (satu) Unit taman kanak-kanak swasta, 1 (satu) unit Sekolah Dasar Negeri dan 1 (satu) unit SLTP Negeri dan belum terdapat SLTA. Tabel 4.1.1 Komposisi Penduduk Desa Mait Hilir menurut Usia

\begin{tabular}{|c|c|c|c|c|}
\hline \multirow{2}{*}{ No } & \multirow{2}{*}{ Usia } & \multicolumn{2}{|c|}{ Jenis Kelamin } & \multirow{2}{*}{ Jumlah } \\
\cline { 3 - 4 } & & Laki-laki & Perempuan & \\
\hline 1 & $0-3$ & 73 & 86 & 159 \\
\hline 2 & $4-6$ & 76 & 82 & 157 \\
\hline 3 & $7-12$ & 66 & 84 & 150 \\
\hline 4 & $13-15$ & 97 & 72 & 169 \\
\hline 5 & $16-18$ & 68 & 63 & 131 \\
\hline 6 & $19-29$ & 76 & 72 & 148 \\
\hline 7 & $30-34$ & 82 & 87 & 169 \\
\hline 8 & $35-44$ & 73 & 70 & 143 \\
\hline 9 & $45-49$ & 67 & 78 & 145 \\
\hline 10 & 50 Keatas & 59 & 77 & 136 \\
\hline \multicolumn{2}{|c|}{ Jumlah } & 737 & 770 & 1.507 \\
\hline
\end{tabular}

Sumber Data : Kantor Desa Mait, 2016

Berdasarkan data tersebut usia produktif di desa Mait Hilir, berusia 13 - 45 tahun terlihat cukup dominan. Dari tingkat pendidikan kita dapat melihat dari tabel berikut :

Tabel 4.1.2 Komposisi Penduduk Berdasarkan Pendidikan

\begin{tabular}{|c|c|c|c|c|}
\hline \multirow{2}{*}{ No } & Tingkat & \multicolumn{2}{|c|}{ Jenis Kelamin } & \multirow{2}{*}{ Jumlah } \\
\cline { 3 - 4 } & Pendidikan & Laki-laki & Perempuan & \\
\hline 1 & $\begin{array}{c}\text { Belum } \\
\text { Sekolah }\end{array}$ & 117 & 134 & 200 \\
\hline 2 & SD & 66 & 93 & 159 \\
\hline 3 & SMP & 319 & 277 & 596 \\
\hline 4 & SMU & 277 & 205 & 482 \\
\hline 5 & D I - D III & 2 & 2 & 4 \\
\hline 6 & $\begin{array}{c}\text { Sarjana ( } \\
\text { S 1 ) }\end{array}$ & 4 & 2 & 6 \\
\hline \multicolumn{2}{|c|}{ Jumlah } & 785 & 722 & 1.507 \\
\hline
\end{tabular}

Sumber Data : Kantor Desa Mait Hilir, 2016

Berdasarkan tabel di atas dapat penulis gambarkan kondisi pendidikan di Desa Mait Hilir, sebagian besar tamatan SMP dan SMA. 
Tabel 4.1.3.Komposisi Berdasarkan Agama

\begin{tabular}{|c|c|c|c|c|c|}
\hline \multirow{2}{*}{ No } & \multirow{2}{*}{ Agama } & \multicolumn{2}{|c|}{ Jenis Kelamin } & \multirow{2}{*}{ Jumlah } & \multirow{2}{*}{ Persentase } \\
\cline { 3 - 4 } & & Laki-laki & Perempuan & & \\
\hline 1 & Katolik & 447 & 351 & 859 & $56,92 \%$ \\
\hline 2 & $\begin{array}{c}\text { Kristen } \\
\text { Protestan }\end{array}$ & 328 & 208 & 536 & $35,56 \%$ \\
\hline 3 & Islam & 73 & 40 & 113 & $7,49 \%$ \\
\hline & Jumlah & 848 & 659 & 1.507 & $100 \%$ \\
\hline
\end{tabular}

Sumber Data, Kantor Desa Mait Hilir

Dari data terebut, hanya terdapat tiga agama yang di anut masyarakat Desa Mait Hilir, yang terbesar adalah Katolik 56,92\%, agama Kristen Protestan 33,56 \% dan Islam sebanyak $7,49 \%$.

Berdasarkan hasil penelitian yang penulis lakukan di Desa Mait Hilir Kecamatan Sepauk bahwa perkawinan di bawah umur tidak dapat dilakukan terkecuali dengan dispensasi dari pengadilan agama. Berdasarkan wawancara penulis dengan Kepala Kantor Urusan Agama (KUA) Kecamatan Sepauk, ada dua pasang Pasangan Perkawinan di Bawah Umur dari Desa Mait Hilir sejak Januari - Juni 2017, yang mengajukan permohonan perkawinan ke kantor Urusan Agama Kecamatan Sepauk yang diberikan Surat Penolakan Perkawinan yang dikeluarkan Pegawai Pencatat Nikah (PPN) karena masih di bawah umur, yaitu pasangan : Andri Budianto dengan Miya Kartina dan Pasangan Fahim dengan Fitriani, ini sesuai dengan syarat undang-undang kedua pasangan tersebut belum memenuhi syarat usia yaitu belum berusia 19 tahun bagi pria dan belum berusia 16 tahun bagi wanita. Tentu saja dengan memberikan pengertian terlebih dahulu bahwa untuk dapat melangsungkan Perkawinan tersebut, maka harus mendapatkan Dispensasi dari Pengadilan Agama.

Atas dasar Surat Penolakan tersebut, KeduaCalonMempelai melalui Kedua Orang tua mengajukan permohonan dispensasi ke Pengadilan Agama dengan rekomendasi dari KUA yang dilampiri dengan Surat Penolakan Perkawinan dari KUA Kecamatan Sepauk. Dari permohonan ini, Pengadilan Agama akan memberikan Penetapan Dispensasi. ${ }^{19}$

Dispensasi dari pengadilan diberikan karena memang benar-benar adanya keadaan memaksa (darurat) sehingga perkawinan harus segera dilangsungkan walaupun calon mempelai berada dibawah umur, misalnya wanita hamil sebelum perkawinan dilangsungkan / hamil di luar nikah. Dalam hal demikian, KUA selaku lembaga pencatatan perkawinan harus mengawinkan/menikahkan calon mempelai yang berada dalam keadaan tersebut.

Namun permohonan penetapan dispensasi tersebut tidak serta merta langsung bisa diperoleh, kedua calon mempelai dan orang tuanya mesti memenuhi persyaratan yang sudah ditetapkan undang-undang. Ada

19 Hasil Wawancara dengan Kepala Kantor Urusan Agama Kecamatan Sepauk 
beberapa persyaratan yang harus dipenuhi

dalam pengajuan permohonan dispensasi

nikah, antara lain: ${ }^{20}$

1. Surat permohonan

2. Fotocopy akta nikah orang tua sebagai pemohon yang bermaterai

3. Surat pemberitahuan penolakan perkawinan dari KUA karena belum cukup umur

4. Fotocopy akta kelahiran calon mempelai laki-laki dan perempuan atau fotocopy ijazah yang sah yang bermaterai

Setelah menerima surat permohonan

Dispensasi kawin, Pengadilan Agama memeriksa perkaranya dengan langkah-

langkah sebagai berikut :

1. Memanggil pihak-pihak yang berperkara

2. Memeriksa kebenaran alasan permohonan pemohon

3. Memeriksa alat-alat bukti

4. Mendengarkan keterangan para saksi atau keluarga dekat

5. Mempertimbangkan maslahat dan mudharat

6. Mengadili dan memutus perkaranya Permohonan dispensasi kawin adalah bersifat voluntair dan produk pengadilan berupa penetapan. Salinan penetapan ini dibuat dan diberikan kepada Pemohon untuk memenuhi persyaratan melangsungkan perkawinan.Jika pemohon tidak puas atas putusan pengadilan, maka dapat mengajukan upaya hukum kasasi ke mahkamah agung.

20 Mahkamah Agung RI, Pedoman Teknis Administrasi dan Teknis Peradilan Agama, Buku II (Jakarta: 2009), hlm 197-198
Salinan penetapan dispensasi nikah akan diserahkan kepada orang tua sebagai pemohon yang nantinya digunakan sebagai pelengkap persyaratan nikah bagi calon mempelai yang masih di bawah umur. Tanpa dispensasi tersebut, perkawinan anak yang masih di bawah umur 19 tahun bagi laki-laki dan umur 16 tahun bagi perempuan akan di tolak oleh Pegawai Pencatat Nikah Kantor Urusan Agama.

Atas dasar pemenuhan syarat dispensasi tersebut maka Kantor Urusan Agama Mencatatkan dan mengesahkan Perkawinan kedua calon mempelai tersebut, sehingga tidak menyalahi aturan.

Adanya Dispensasi dari pengadilan diberikan karena memang benar-benar adanya keadaan memaksa (darurat) sehingga perkawinan harus segera dilangsungkan walaupun calon mempelai berada dibawah umur, misalnya wanita hamil sebelum perkawinan dilangsungkan / hamil di luar nikah. Dalam hal demikian, KUA selaku lembaga pencatatan perkawinan harus mengawinkan/menikahkan calon mempelai yang berada dalam keadaan tersebut.

Ini berarti bahwa syarat perkawinan dari sisi usia tidak dapat dipenuhi, namun tetap dilakukan oleh karena bersifat darurat dan atau memaksa, yang menjadi dasar penetapan sehingga tidak melanggar hukum islam. Dan 
keadaan seperti inilah yang menyebabkan diabaikannya syarat usia dariUndangUndang Perkawinan nomor Itahun 1974 tentang Perkawinan. Tidak terpenuhinya dispensasi bagi Perkawinan di Bawah Umur menyebabkan tidak tercatatnya Perkawinan tersebut di Akta Nikah dan tidak sahnya perkawinan tersebut secara hukum Negara.

\section{B. Penyebab Perkawinan di bawah umur di Desa Mait Hilir Kecamatan Sepauk Kabupaten Sintang?}

Dari hasil wawancara yang penulis lakukan dan dianalisis dengan menggunakan teori para ahli diperoleh penyebaab Perkawinan Dibawah Umur antara lain disebabkan oleh :

\section{Faktor Ekonomi ;}

Sebagian besar $84 \%$ dari 1.507 Jiwa Penduduk Desa Mait hilir adalah petani, yang mengharapkan mata pencahariannya sehari hari dengan bercocok tanam dan menyadap karet dengan penghasilan yang tidak menentu karena sangat tergantung juga dengan kondisi cuaca. Dari pengamatan dan wawancara yang penulis lakukan Kondisi ekonomi yang sulit ini memiliki pengaruh yang besar terutama keluarga si gadis diamana orang tuanya meminta keluarga laki-laki untuk mengawinkan anak gadisnya, sehingga beban keluarga dalam membiayai sekolah, sandang, pangan akan semakin berkurang karena dalam keluarga gadis akan berkurang satu anggota keluarganya yang menjadi tanggung jawab orang tuanya, karena akan menjadi tanggung jawab suami. Jadi begitu anaknya sudah baligh segera dinikahkan untuk meringankan beban keluarga. Dan orang tua biasanya menikahkan anaknya dengan Laki-laki dari keluarga yang lebih mapan dari sisi ekonomi.

\section{Rendahnya Tingkat Pendidikan}

Sebagian warga Desa Mait Hilir hanya berpendidikan SD dan SMP sebesar 755 orang atau $50 \%$ dari 1.507 jiwa. Tentu saja dengan tingkat pendidikan yang rendah mempengaruhi juga pengetahuan dan realitas hidup di masyarakat sehingga Perkawinan di bawah umur dianggap sebagai sesuatu yang lumrah terjadi di masyarakat dan justru memberikan keuntungan, antara lain meringankan beban ekonomi keluarga, mencegah zina yang dilarang oleh agama hal ini diakui juga oleh Kepala desa Mait Hilir dimana Perkawinan di bawah umur dianggap suatu hal yang biasa terjadi dan bukan sesuatu hal yang luar biasa, karena pemahaman akan UU Nomor 1 Tahun 1974 juga masih terbatas dikarenakan tingkat pendidikan yang minim dan wawaan yang terbatas.

\section{Budaya Masyarakat Setempat}

Perkawinan Usia dini juga dipengaruhi 
oleh budaya di Desa Maid dimana orang tua takut anaknya dianggap perawan tua atau bujang tua yang akan menjadi cemoohan dan bahan ejekan warga masyarakat sekitar sehingga dianggap aib bagi keluarga, fenomena ini menjadi sebuah budaya yang menghantui secara terus menerus dengan menanamkan stigma negatif terhadap perawan tua atau bujang tua. Apalagi lingkungan sosial masyarakat dalam pergaulan sehari hari selalu mempertanyakan kepada para orang tua di kampung sudah menimang cucu atau belum, sudah mendapat mantuatau belum. Ketakutan ini mendorong orang tua untuk menikahkan anaknya di usia yang masih dini atau di bawah umur.

\section{Pergaulan Bebas}

Pergaulan bebas yang terjadi di kalangan anak muda dewasa ini juga sangat berpengaruh besar, karena pergaulan bebas menjadi stempel bagi anak-anak modern sehingga trend ini di ikuti oleh anak anak usia remaja dalam pergaulan sehari-hari karena takut dikatakan ketinggalan jaman, kurang pergaulan yang terkadang menafikkan etika dan sopan santun yang ada di masyarakat, pergaulan bebas juga merambah ke Desa Mait Hilir ini, dimana anak remaja melupakan etika yang menyebabkan kehamilan dan pada akhirnya putus sekolah dan kawin muda kebanyakan dilakukan dengan kawin adat, tanpa melaporkan ke KUA atau Gereja. Karena terkendala UU Perkawinan.

\section{Pengaruh Dunia Maya}

Teknologi Informasi dan Telekomunikasi yang demikian majujugatelah merubah wajah dunia, orang dapat dengan mudah berkomunikasi tanpa terkendala jarak, waktu, biaya yang murah dan serba mudah, namun efek negative teknologi juga dapat terjadi jika digunakan tanpa melihat sisi positif dan negatifnya. Anak muda akan mudah untuk mengakses gambar-gambar, filem-filem dan konten-konten dewasa yang belum seharusnya mereka lihat, tentu persoalan ini menjadi virus yang enakutkan yang akan mendorong perilaku termasuklah dalam hal pergaulan, hal ini terjadi hamper semua daerah hingga pelosok-pelosok kampung termasuklah di Desa Mait hilir ini anak-anak remaja sudah terbiasa menggunakan smartphone, berselancar di media sosial, berkomunikasi dengan pasangannya. Kemudahan dalam berkomunikasi dan mendapatkan akses informasi secara tidak terkendali juga menjadi pendorong perkawinan di bawah umur, seperti bertemu di dunia maya berkenalan dan janjian ketemu di Sintang atau di sepauk tanpa tahu dan mengenal latar belakang teman dunia maya sehingga terjadi hal-hal yang tidak di 
inginkan.

Selain itu Undang-Undang Perkawinan Nomor 1 Tahun 1974 belum banyak diketahui masyarakat, hal ini menandakan kurang efektifnya pemberlakuan Undang-Undang, karena pembuatan Undang-Undang tentu saja mesti memenuhi syarat Historis, Filosopis dan Sosiologis. Namun dalam kenyataannya belum maksimal, ini disebabkan oleh :

\section{Faktor Hukumnya Sendiri (undang- undang)}

Dari sisi faktor hukumnya sendiri, secara umum sudah cukup baik dan sistematis yang mengedepankan juga hukum agama dari masing-masing mempelai. Undang-undang Perkawinan Nomor I Tahun 1974 bab II pasal 7 ayat 1 disebutkan bahwa :perkawinan hanya diizinkan jika pihak pria mencapai umur 19 (sembilan belas) tahun dan pihak perempuan sudah mencapai umur 16 (enam belas tahun) tahun. Pernyataan diizinkan ini, berarti membatasi usia bagi masing-masing calon mempelai haruslah sesuai dengan aturan yaitu pria berusia 19 tahun dan perempuan berusia 16 tahun. Namun Undang-undang juga dapat mengizinkan perkawinan di bawah umur dengan adanya persyaratan dispensasi, hal ini tentu akan mendorong tetap dilakukannya pelanggaran-pelanggaran terhadap aturan tersebut karena ada solusi melalui Dispensasi Pengadilan Agama.
1. Faktor Penegak Hukum, yang menerapkan hukum

Dari sisi faktor penegak hukum itu sendiri dalam hal ini KANTOR Urusan Agama ketika penulis mewawancarai Bapak Mursi, S.Ag Petugas Pencatat Nikah di KUA Sepauk, beliau menyatakan bahwa Perkawinan di bawah umur adalah sesuatu yang melanggar Undang-undang Perkawinan Nomor 1 Tahun 1974, sehingga dalam kasus seperti ini kami memberikan Surat Penolakan Perkawinan yang dikeluarkan oleh Pegawai Pencatat Nikah Kantor Urusan Agama dan Memberikan Jalan Keluar kepada kedua Orang Tua Calon Mempelai untuk membuat Laporan tertulis ke KUA sebagai dasar Kantor Urusan Agama memberikan Rekomendasi untuk mohon penetapan Dispensasi dari Pengadilan Agama Sintang oleh karena keadaan memaksa hal ini jika memang Perkawinan itu harus dilakukan guna menghindari terjadinya zina yang melanggar syariah, apalagi rata rata pasangan tersebut sudah mendapatkan izin dari orang tua masing-masing dan sudah tidak bisa di tunda-tunda lagi perkawinannya.

Dalam memberikan Surat Penolakan Perkawinan Pegawai Pencatat Nikah juga juga memberikan nasehat, kepada calon mempelai maupun orang tua kedua calon mempelai Perkawinan tentang dampak buruk Perkawinan Di Bawah Umur, namun tentu 
saja karena sudah sama-sama mau dan darurat, maka prosedur Dispensasi haruslah menjadi jalan keluar yang diberikan untuk kemudian menjadi syarat Pencatatan Perkawinan di Kantor Urusan Agama Sepauk.

\section{Faktor sarana atau fasilitas yang} mendukung penegakan hukum

Faktor Sarana dan Prasarana Penegakan Hukum juga terkadang menjadi kendala dalam upaya penegakan hukum, hal ini cukup terasa khususnya di KUA Sepauk yang wilyah kerjanya mencakup semua desa yang berada di Kecmatan Sepauk, khususnya desa-desa pedalaman yang jarak dan medannya berat, untuk melakukan sosialisasi UndangUndang Perkawinan agar dapat diketahui oleh masyarakat juga terkadang tidak dapat kita lakukan karena malah cuaca yang menyebabkan jalan tidak dapat dilalui oleh kendaraan biasa, mesti menggunakan motor trail atau kendaraan dobel gardan, sehingga ini menjadi kendala kami melakukan sosialisasi ke desa-desa di wilayah pedalaman yang medannya sulit. Tentu saja keinginan kami dalam mensosialisasikan UU Perkawinan No 1 Tahun 1974 ini juga mesti ditunjang dengan fasilitas serta sarana dan prasarana lainnya.

\section{Faktor masyarakat, Yakni lingkungan Dimana Hukum Tersebut Berlaku atau Diterapkan.} Meskipun Undang-Undang Perkawinan Nomor I Tahun 1974 telah mengatur tentang Perkawinan, namun kepatuhan masyarakat akan Peraturan ini belumlah maksimal dari hasil wawancara dengan Orang tua yang anaknya Melakukan Perkawinan di bawah umur, yaitu Bapak Hidayat dan Ibu Sriyatun didapati kenyataan bahwa mereka baru mengerti batasan Usia dari UU Nomor 1 Tahun 1974 ketika disampaikan oleh petugas di KUA itupun pada saat mengurus Perkawinan Anaknya, dan hal ini juga dibenarkan oleh Kepala Desa Mait Hilir Bapak Endrianus Juta, dimana masyarakat di Desanya kebanyakan tidak memahami Undang-Undang Perkawinan Nomor 1 Tahun 1974, karena kurangnya sosialisasi dan Pengetahuan yang minim dikarenakan rendahnya tingkat pendidikan, sehingga menganggap Perkawinan di bawah umur sesuatu yang biasa, karena murni keinginan kedua calon mempelai dan kedua orang tua calon mempelai sudah sepakat untuk menikahkan putra putri mereka.

Dari pihak Desa juga pernah memberikan saran pendapat terhadap kasuskasus yang demikian dengan memanggil orang tua yang bersangkutan namun semuanya kembali lagi pada orang tua masing-masing yang telah memberikan izin kepada anknya untuk melangsunkgan Perkawinan.

Ada pula alasan bahwa calon pasangan sudah teralu lama pacaran dan sudah tinggal 
serumah sehingga untuk menghindari hal yang negatif yang menjurus ke Dosa maka di nikahkan, memang alasannya pembenarannya beragam dan semuanya memang harus segera juga di nikahkan karena alasan-alasan tersebut masuk akal jika kita melihat kondisi kedua calon mempelai tersebut.

Elemen tersebut di atas memberikan pemahaman bahwa disiplin dan kepatuhan masyarakat tergantung dari motivasi yang secara internal muncul. Internalisasi faktor ini ada pada tiap individu yang menjadi elemen terkecil dari komunitas sosial. Oleh karena itu pendekatan paling tepat dalam hubungan disiplin ini adalah melalui motivasi yang ditanamkan secara individual. Dalam hal ini, derajat kepatuhan hukum masyarakat menjadi salah satu parameter tentang efektif atau tidaknya hukum itu diberlakukan sedangkan kepatuhan masyarakat tersebut dapat dimotivasi oleh berbagai penyebab, baik yang ditimbulkan oleh kondisi internal maupun eksternal.

\section{Faktor kebudayaan, dan Budaya Hukum}

Pengaruh budaya lokal, yang bersumber dari kebiasaan juga memegang peranan penting untuk efektif tidaknya suatu peraturan itu dapat diterapkan di masyarakat. Hasil wawancara dengan Orang Tua Pasangan Perkawinan di bawah umur, menunjukkan bahwa di desa Mait Hilir juga ada Budaya untuk mengawinkan anak yang sudah baligh dikarenakan ketakutan tidak mendaptkan jodoh ketika usia semakin tua sehingga di cap sebagai Perawan tua atau Bujang Tua, hal ini dipengaruhi adat istiadat lama baik di masyarakat Dayak, maupun masyarakat transmigrasi yang tinggal di Desa Mait, Budaya ini juga mendorong terjadinya Perkawinan di bawah umur, selain itu menurut wawancara dengan Seretaris Desa usia produktif di Desa juga sangat mempengaruhi, karena Perkawinan di Usia Muda bisa menjamin kehidupan bagi anak-anak yang nanti dilahirkan, karena kedua orang tuanya punya waktu yang cukup untuk bekerja guna mencukupi kebutuhan sehari-hari, makan, minum sekolah hingga menikahkan anaknya kelak dalam arti orang tua masih mampu bekerja sebelum anaknya menikah, dibandingkan dengan menikah di usia tua atau dewasa diman anak-anaknya belum cukup umur, orang tuanya sudah tidak lagi mmpu bekerja karena faktor usia yang sudah lanjut, tentu budaya ini di kalangan tertentu masih menjadi pedoman sehari-hari yang juga menjadi salah satu penyebab Perkawinan di bawah umur.

Namun dari semua responden baik Kepala Desa, Sekretaris Desa, Pegawai Pencatat Nikah Kantor Urusan Agama 
mengatakan bahwa perkawinan di bawah umur sedapat mungkin harus dihindari, karena usia yang ditetapkan oeh Undangundang tentunya sudah mendapatkan kajian yang mendalam sehubungan dengan makna perkawinan itu sendiri dimana Perkawinan ialah ikatan lahir bathin antara seorang pria dan wanita sebagai suami-isteri dengan tujuan membentuk keluarga yang bahagia, baik lahir maupun bathin berdasarkan Ketuhanan Yang Maha Esa.

\section{DAFTAR PUSTAKA}

Amir, Syarifudin. 2006. Hukum Perkawinan Islam di Indonesia". Jakarta : Prenada Media.

Cholil, Mansyur. 1994. Sosiologi Kota dan Desa. Surabaya : Usaha nasional.

Satjipto, Raharjo. 2000. Ilmu Hukum. Bandung : Citra Aditya.

Kartono, Kartini. 1992. Patologi Sosial. Jakarta : Rajawali Press.

R. Soeroso. 2006. Pengantar Ilmu hukum. Jakarta : Sinar Grafika.

Siswanto, Wilopo. A. 2004. Ada Apa Dengan Gender? Badan Kependudukan dan keluarga Berencana nasional (Bkkbn). Jakarta.

Martiman, Prodjoamidjojo. 2007. Hukum perkawinan Indonesia. Indonesia Legal Center Publishing. Jakarta.

R. Soeroso. 2006. Pengantar Ilmu Hukum. Jakarta : Sinar Grafika.

Sarlito, Sarwono. 1991. Teori Psikologi Sosial. Jakarta. CV. Rajawali.

Soerjono, Soekamto. 1998. Efektifitas Hukum dan Penerapan Sanksi. Bandung. CV. Remadja Karya. 2008. Faktor Yang Mempengaruhi Penegakan Hukum. Jakarta : PT. Raja Grafindo Persada.

Syafik, Hasyim. 1999. Menakar Harga Perempuan. Bandung : Mirzan.
Wiryono, Prodjodikoro. Hukum Perkawinan. Bandung Alumni.

\section{Perundang-Undangan:}

Kitab Undang-Undang hukum Perdata (KUH Perdata) Tri Permata Press.

Undang-Undang Nomor 1 Tahun 1974 Tentang Perkawinan Dan Kompilasi Hukum Islam. Cetakan ke I Sinar Sindo Utama Surabaya. Tahun 2015.

Peraturan Pemerintah Nomor 9 Tahun 1975 Tentang Pelaksanaan UndangUndang Nomor 1 Tahun 1974 Tentang Perkawinan. 